\title{
Differential modulation of mitogenic and metabolic actions of insulin-like growth factor I in rat glomerular mesangial cells in high glucose culture
}

\author{
R. Kikkawa, M. Haneda, M. Togawa, D. Koya, N. Kajiwara and Y. Shigeta \\ The Third Department of Medicine, Shiga University of Medical Science, Otsu, Shiga, Japan
}

\begin{abstract}
Summary. In order to explore the possible contribution of insulin-like growth factor I to the development of diabetic nephropathy, the effect of glucose on the mitogenic and metabolic actions of insulin-like growth factor I in cultured rat glomerular mesangial cells was examined. The stimulation of $\left[{ }^{3} \mathrm{H}\right]$-thymidine incorporation by insulin-like growth factor I in the cells exposed to high concentrations $(55 \mathrm{mmol} / \mathrm{l})$ of glucose (4.6 \pm 1.3 fold stimulation) was significantly suppressed as compared with that in the cells cultured in $11 \mathrm{mmol} / \mathrm{l}$ glucose $(17.5 \pm 0.8$ fold $)$. In contrast, $\left[{ }^{3} \mathrm{H}\right]$-aminoisobutylic acid uptake into the mesangial cells was significantly enhanced by glucose $\left(2.03 \pm 0.03 \mathrm{nmol} \cdot \mathrm{mg} \mathrm{protein}^{-1}\right.$. $15 \mathrm{~min}^{-1}$ at $55 \mathrm{mmol} / \mathrm{l}$ glucose vs $0.59 \pm 0.01$ at $11 \mathrm{mmol} / \mathrm{l}$ glucose), while 2-deoxyglucose uptake remained unchanged. $\left[{ }^{125} \mathrm{I}\right]$-insulin-like growth factor I binding was slightly but sig-
\end{abstract}

nificantly increased in the cells exposed to high concentrations of glucose. Thus, glucose may modulate the mitogenic and metabolic actions of insulin-like growth factor I differently in cultured mesangial cells probably at the post-insulinlike growth factor I receptor level. These results may indicate that the differential modulation of the actions of insulin-like growth factor I by glucose could result in the increase in amino acid uptake and decrease in the cell proliferation in the mesangial cells, possibly leading to enhanced mesangial matrix synthesis with a relatively small increase in mesangial cell volume as seen in diabetic nephropathy.

Key words: Diabetic nephropathy, glomerular mesangial cells, insulin-like growth factor I, proliferation, amino acid uptake, mesangial expansion, effect of glucose.
Diabetic nephropathy is characterized by the expansion of the glomerular mesangium with a relatively small increase in mesangial cell volume $[1,2]$. The mesangial expansion is considered to be due to the accumulation of various macromolecules including type IV collagen in mesangial matrix [3]. We and others $[4,5]$ have previously described that the production of type IV collagen is enhanced in the glomerular mesangial cells cultured in high concentrations of glucose. Therefore, the alteration of the function of mesangial cells under high glucose conditions may play an important role in the development of diabetic nephropathy.

Insulin-like growth factor I (IGF-I) is one of the candidates which could affect the function of the mesangial cells. The cultured mesangial cells possess a considerable number of receptors specific to IGF-I and proliferate in response to IGF-I [6-8]. Moreover, the uptake of glucose and amino acid is regulated by IGF-I at physiological concentrations [8]. Although the production of IGF-I in the kidney has been reported to be enhanced in diabetic rats [9], the effect of these altered IGF-I levels on the mesangial cells has not been clarified. Therefore, we exam- ined the effect of glucose on both mitogenic and metabolic actions of IGF-I in cultured glomerular mesangial cells.

\section{Materials and methods}

\section{Materials}

Human biosynthetic IGF-I was kindly supplied by Fujisawa Pharmaceutical Company (Osaka, Japan). $\mathrm{Na}^{125} \mathrm{I}, \mathrm{D}-\left[\mathrm{U}-{ }^{14} \mathrm{C}\right]$ glucose, 2deoxy $\left[1-{ }^{3} \mathrm{H}\right]$ glucose $(2-D O G), \alpha-\left[\right.$ methyl- $\left.{ }^{3} \mathrm{H}\right]$ aminoisobutylic acid (AIB), and $\left[6{ }^{3} \mathrm{H}\right]$ thymidine were purchased from New England Nuclear (Boston, Mass., USA). Fetal bovine serum was purchased from Gibco (Grand Island, NY, USA). All other reagents were of chemical grade and purchased from standard suppliers.

\section{Cell culture and experimental protocol}

Glomeruli were isolated from kidneys of Sprague-Dawley rats weighing $100-150 \mathrm{~g}$ by sieving with stainless steel and nylon meshes under sterile conditions as previously reported $[8,10]$. Isolated 
glomeruli were then cultured in RPMI 1640 medium containing $20 \%$ fetal bovine serum and antibiotics. Cultured cells were identified as mesangial cells using the following criteria as previously described $[8,10]:$ : (1) the cells survived in a medium containing $\mathrm{D}$-valine which had been substituted for $\mathrm{L}$-valine, indicating existence of Damino acid oxidase; (2) they were resistant to puromycin aminonucleoside $(10 \mu \mathrm{g} / \mathrm{ml})$ but susceptible to mitomycin C $(10 \mu \mathrm{g} / \mathrm{ml})$; (3) they possessed a large number of intracellular actin bundles stained by peroxidase-conjugated heavy melo-myosin; (4) they had receptors specific to angiotensin II and contracted in response to angiotensin II. The cells at 5-12 passages were grown on $35 \mathrm{~mm}$ sixwell plates unless otherwise specified and used for the following experiments after confluency.

After washing with phosphate-buffered saline (PBS; $137 \mathrm{mmol} / \mathrm{l}$ $\mathrm{NaCl}, 2.7 \mathrm{mmol} / \mathrm{KCl}, 8 \mathrm{mmol} / \mathrm{l} \mathrm{Na} \mathrm{NPO}_{4}, 1.5 \mathrm{mmol} / 1 \quad \mathrm{KH}_{2} \mathrm{PO}_{4}$, $\mathrm{pH} 7.5$ ), the confluent cells were cultured in RPMI 1640 medium (11.1 mmol// glucose) with $0.4 \%$ fetal bovine serum for 2 days and then in RPMI 1640 medium (glucose free) supplemented with various concentrations $(5.5-55 \mathrm{mmol} / 1)$ of glucose with $0.4 \%$ fetal bovine serum for an additional 3 days. Mannitol was used to mimic the hyperosmolar effect of glucose. IGF-I binding, the incorporation of $\left[{ }^{3} \mathrm{H}\right]$-thymidine, and the uptake of AIB or 2-DOG were then examined by previously described methods [8].

\section{IGF-I binding}

${ }^{125} \mathrm{I}-\mathrm{IGF}-\mathrm{I}$ with a specific activity of $100-150 \mu \mathrm{Ci} / \mu \mathrm{g}$ was prepared according to the method of Freychet et al. [11]. Cells on $100 \mathrm{~mm}$ plates were washed three times with PBS and incubated with labelled $(0.2 \mathrm{ng} / \mathrm{ml})$ and various amounts of unlabelled IGF-I at $4^{\circ} \mathrm{C}$ for $16 \mathrm{~h}$ in a buffer containing $50 \mathrm{mmol} / 1$ Tris, $50 \mathrm{mmol} / \mathrm{l} \mathrm{N}$-(2-hydroxyethyl)piperazine- $\mathrm{N}^{\prime}$-2-ethanesulphonic acid (HEPES), $50 \mathrm{mmol} / \mathrm{l} \mathrm{NaCl}$, $5 \mathrm{mmol} / \mathrm{l} \mathrm{KCl}, 10 \mathrm{mmol} / 1 \mathrm{MgSO}_{4}, 10 \mathrm{mmol} / \mathrm{l} \mathrm{CaCl}, 10 \mathrm{mmol} / \mathrm{l} \mathrm{glu}-$ cose, $2 \mathrm{mmol} / \mathrm{l}$ EDTA, and $1 \%$ bovine serum albumin (BSA) ( $\mathrm{pH}$ 8.0). After the incubation, cells were washed five times with icecold $\mathrm{PBS}$ and solubilized with $1 \mathrm{~mol} / \mathrm{lNaOH}$. The radioactivity associated with the cells was then determined in a gamma counter.

\section{Thymidine incorporation}

Thymidine incorporation was measured by the method of Flier et al. [12] with some modifications. In brief, cells were rinsed with PBS and incubated with RPMI 1640 with $0.4 \%$ BSA, pH 7.4, for $48 \mathrm{~h}$ at $37^{\circ} \mathrm{C}$ in a $\mathrm{CO}_{2}$ incubator. The medium was replaced with RPMI 1640 containing $0.25 \% \mathrm{BSA}$ and various concentrations of IGF-I. After a 20 -h incubation with IGF-I, $\left[{ }^{3} \mathrm{H}\right]$ thymidine was added to a final concentration of $1.5 \mu \mathrm{Ci} / \mathrm{ml}$ and incubation was continued for additional $4 \mathrm{~h}$ at $37^{\circ} \mathrm{C}$ in a $\mathrm{CO}_{2}$ incubator. Cells were then cooled on ice, washed two times with PBS, two times with $10 \%$ TCA and one time with $95 \%$ ethanol, and solubilized with $1 \mathrm{~mol} / \mathrm{l} \mathrm{NaOH}$. The radioactivity remaining within the cells was determined in a liquid scintillation counter.

\section{$\alpha$-Aminoisobutylic acid uptake}

$\alpha$-Aminoisobutylic acid (AIB) uptake was measured by the method of Knight et al. [13]. In brief, cells were rinsed two times and pre-incubated with Earle's balanced salt solution supplemented with $25 \mathrm{mmol} / 1 \mathrm{NaHCO}_{3}$ and $0.1 \% \mathrm{BSA}, \mathrm{pH} 7.4$, at $37^{\circ} \mathrm{C}$ for $2 \mathrm{~h}$ in a $\mathrm{CO}_{2}$ incubator. The medium was then replaced with the same solution without $\mathrm{NaHCO}_{3}$ and with $25 \mathrm{mmol} / \mathrm{l}$ HEPES, pH 7.6, containing various concentrations of IGF-I. After $3 \mathrm{~h}$ at $37^{\circ} \mathrm{C}$ in the absence of $\mathrm{CO}_{2},\left[{ }^{3} \mathrm{H}\right] \mathrm{AIB}$ and unlabelled AIB were added to a final concentration of $0.1 \mu \mathrm{Ci} / \mathrm{ml}$ and $8 \mu \mathrm{mol} / 1$, respectively. After $15 \mathrm{~min}$, AIB uptake was terminated by washing rapidly three times with ice-cold
PBS. The radioactivity remaining within the cells was determined as described above.

\section{2-Deoxyglucose uptake}

Uptake of 2-deoxyglucose (2-DOG) by mesangial cells was determined by the method of McClain et al. [14]. In brief, cells were, first, pre-incubated with RPMI 1640 medium containing $0.5 \%$ BSA at $37^{\circ} \mathrm{C}$ in a $\mathrm{CO}_{2}$ incubator for $18 \mathrm{~h}$. Cells were rinsed three times with Krebs-Ringer Phosphate (KRP)-HEPES buffer, $\mathrm{pH} 7.45$, containing $131.2 \mathrm{mmol} / \mathrm{l} \mathrm{NaCl}, 4.71 \mathrm{mmol} / \mathrm{KCl}, 2.47 \mathrm{mmol} / 1 \mathrm{CaCl}_{2}$, $1.24 \mathrm{mmol} / 1 \mathrm{MgSO}_{4}, 2.48 \mathrm{mmol} / / \mathrm{NaH}_{2} \mathrm{PO}_{4}, 10 \mathrm{mmol} / \mathrm{l} \mathrm{HEPES}$, and $0.5 \% \mathrm{BSA}$ and pre-incubated again with the same buffer at $37^{\circ} \mathrm{C}$ for 30 min. Fresh KRP-HEPES buffer containing various concentrations of IGF-I was then introduced. After a 1-h incubation with IGFI at $37^{\circ} \mathrm{C}, 2$-deoxy $\left[1-{ }^{3} \mathrm{H}\right]$ glucose and unlabelled 2-DOG were added to a final concentration of $0.1 \mu \mathrm{Ci} / \mathrm{ml}$ and $0.1 \mathrm{mmol} / 1$, respectively, and incubation was continued at $37^{\circ} \mathrm{C}$ for $5 \mathrm{~min}$. Incubation was terminated by rapid aspiration of the buffer, chilling on ice and washing three times rapidly with ice-cold PBS. Cells were then solubilized with $1 \mathrm{~mol} / \mathrm{l} \mathrm{NaOH}$ and the radioactivity remaining within the cells was determined by a liquid scintillation counter.

\section{Statistical analysis}

Results are presented as mean \pm SD. Comparison between two groups were done by unpaired $t$-test. Comparisons among three or more groups were done by one-way analysis of variance (ANOVA) followed by Scheffe's test to evaluate statistical significance between any two groups.

\section{Results}

\section{IGF-I binding}

Specific tracer binding of IGF-I to the mesangial cells cultured in $55 \mathrm{mmol} / \mathrm{l}$ glucose was increased significantly as compared with the cells cultured in $11 \mathrm{mmol}$ glucose (Fig.1). Similar increases in IGF-I binding were observed when the cells were cultured under hyperosmolar conditions induced by adding mannitol to the culture media



Fig. 1. Insulin-like growth factor I (IGF-I) binding to the mesangial cells cultured under $11 \mathrm{mmol} / \mathrm{l}$ glucose $(O), 55 \mathrm{mmol} / 1$ glucose (-) or $11 \mathrm{mmol} / \mathrm{l}$ glucose plus $44 \mathrm{mmol} / \mathrm{l}$ mannitol $(\triangle)$. Scatchard plot is shown in the inset. Values are mean of four experiments 

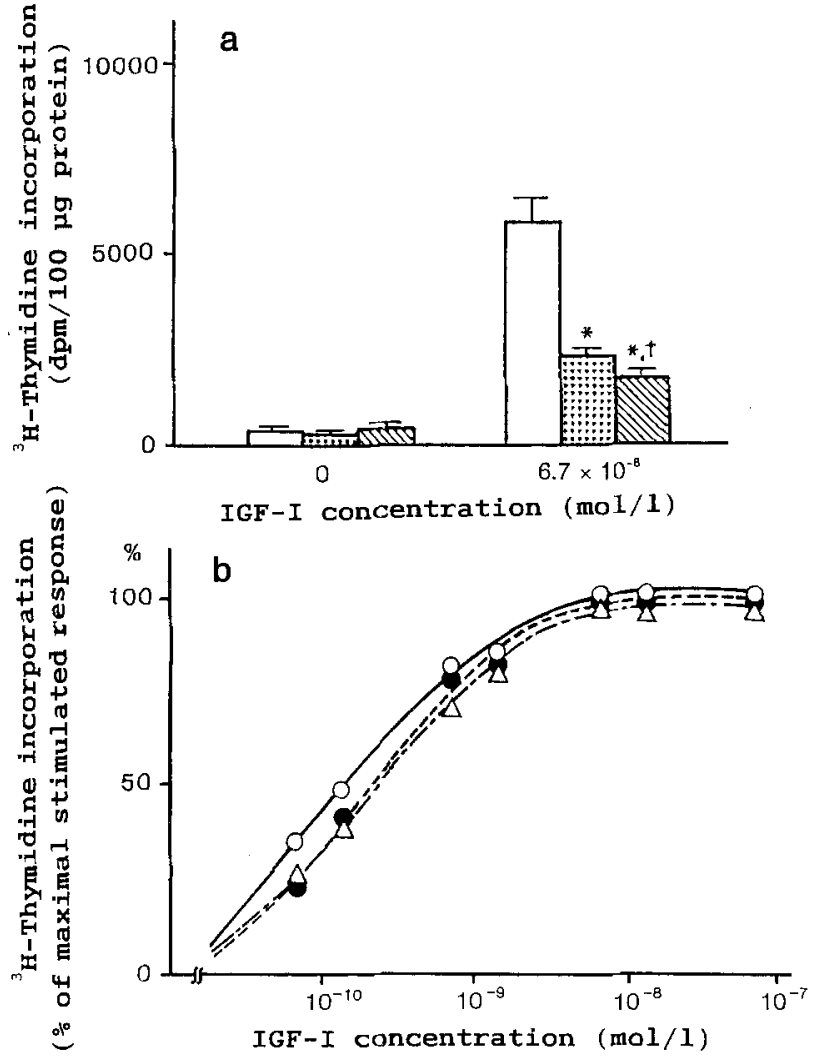

Fig. 2a,b. Basal and insulin-like growth factor I (IGF-I)-stimulated $\left[{ }^{3} \mathrm{H}\right]$-thymidine incorporation into the mesangial cells (a) and doseresponse curve of IGF-I (b). The cells were cultured under $11 \mathrm{mmol} / \mathrm{lglucose}$ (control; $\mathbf{a}, \square, \mathbf{b}, 0$ ), $55 \mathrm{mmol} / \mathrm{l}$ glucose (high glucose; $\mathbf{a}, \boldsymbol{\Xi}, \mathbf{b}, \mathbf{0})$ or $11 \mathrm{mmol} / \mathrm{l}$ glucose plus $44 \mathrm{mmol} / \mathrm{l}$ mannitol (mannitol; $\mathbf{a}$, : $, \mathbf{b}, \triangle$ ). Values are mean \pm SD of three experiments in a and mean of three experiments in $\mathbf{b}$. $* p<0.01$ vs control; $+p<0.01$ vs mannitol

(Fig. 1). As shown in Figure 1, the increase in IGF-1 binding in hyperglycaemic $(55 \mathrm{mmol} / \mathrm{l}$ glucose $)$ or hyperosmotic (mannitol) conditions was due to the increase in receptor number without any change in receptor affinity,

\section{Thymidine incorporation}

In order to evaluate the ability of IGF-I to stimulate the proliferation of the mesangial cells, the incorporation of $\left[{ }^{3} \mathrm{H}\right]$-thymidine into the cells cultured under various concentrations of glucose was examined. The incorporation of $\left[{ }^{3} \mathrm{H}\right]$-thymidine stimulated by $6.7 \times 10^{-8} \mathrm{~mol} / 1 \mathrm{IGF}-\mathrm{I}$ (the maximal response) was significantly inhibited in the cells cultured in $55 \mathrm{mmol} / \mathrm{l}$ glucose (Fig. 2a). Slight but significant inhibition (11.4\% inhibition) was observed in the cells cultured in $27.5 \mathrm{mmol} / \mathrm{l}$ glucose. Similar inhibition, though less prominent, was observed in the cells cultured in the presence of mannitol (Fig.2a). However, when the dose-response curve of IGF-I to stimulate the incorporation of thymidine was expressed as the percent of maximal stimulated response, the curve was similar among control, high glucose, and mannitol groups (Fig. 2b), indicating the alteration of IGF-I action at the post-receptor levels.

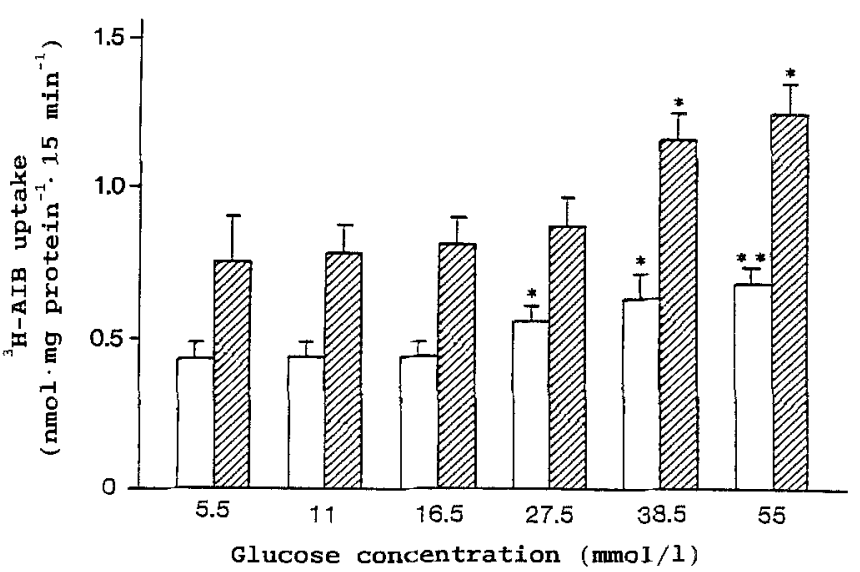

Fig.3. $\alpha$-Aminoisobutylic acid (AIB) uptake in the mesangial cells cultured under various concentrations of ghcose. Basal ( $\square$ ) and insulin-like growth factor I $\left(6.7 \times 10^{-8} \mathrm{~mol} / \mathrm{l}\right)$-stimulated $(\square)$ values are shown. Values are mean $\pm \mathrm{SD}(n=3),{ }^{*} p<0.05$, *** $p<0.01$ vs $5.5 \mathrm{mmol} / \mathrm{lglucose}$

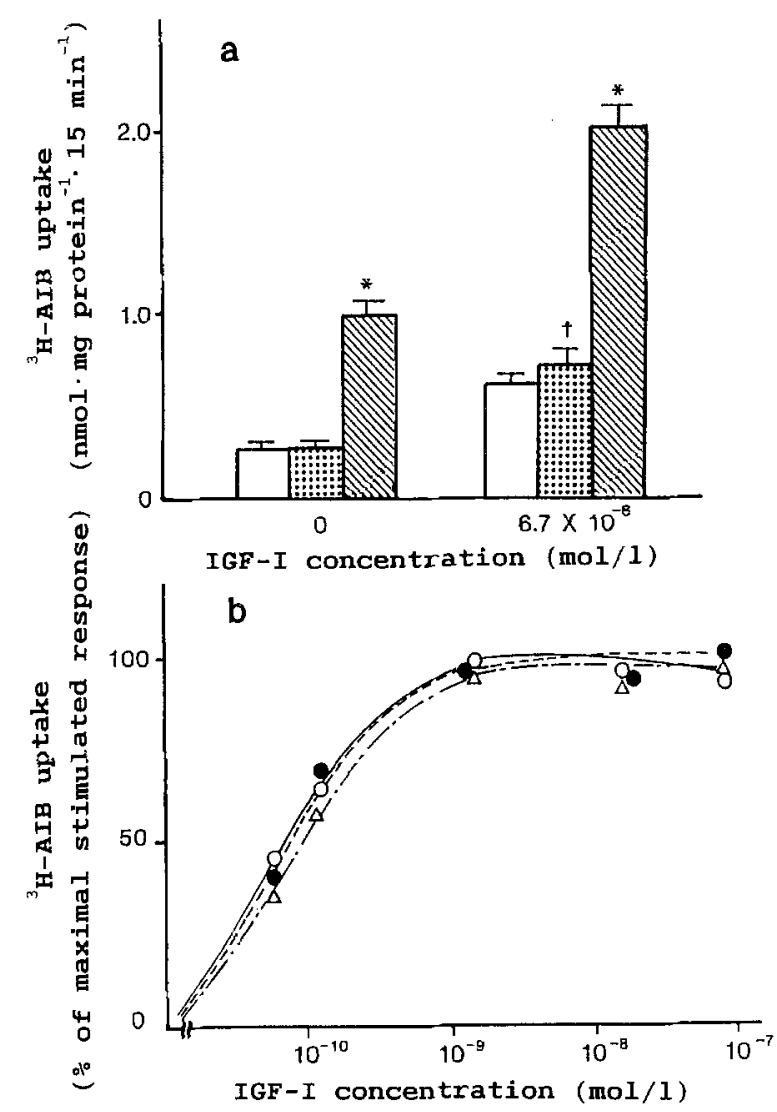

Fig. 4a,b. Basal and insulin-like growth factor I (IGF-I)-stimulated $\alpha$-aminoisobutylic acid (AIB) uptake in the mesangial cells (a) and dose-response curve of IGF-I (b). The cells were cultured as described in Figure 2. Vahues are mean $\pm \operatorname{SD}(n=3)$, ${ }^{*} p<0.01$ vs control and mannitol; $+p<0.01$ vs control

\section{$\alpha-$ Aminoisobutylic acid uptake}

Since IGF-I was able to stimulate the uptake of amino acid and glucose as well as thymidine at physiological concentrations in cultured mesangial cells [8], $\alpha$-aminoisobutylic acid (AIB) uptake was next examined. In contrast to thy- 
Table 1. 2-Deoxyglucose (2-DOG) uptake in cultured mesangial cells

\begin{tabular}{lll}
\hline Culture conditions & \multicolumn{2}{l}{$\begin{array}{l}\text { 2-DOG uptake } \\
\left.\text { (nmol } \cdot \mathrm{mg} \mathrm{protein}^{-1} \cdot 5 \mathrm{~min}^{-1}\right)\end{array}$} \\
\cline { 2 - 3 } & Basal & IGF-I $\left(6.7 \times 10^{-8} \mathrm{~mol} / \mathrm{l}\right)$ \\
\hline $11 \mathrm{mmol} / \mathrm{l}$ Glucose & $5.72 \pm 0.3$ & $7.35 \pm 0.6$ \\
$55 \mathrm{mmol} / \mathrm{G}$ Glucose & $5.84 \pm 0.3$ & $7.83 \pm 0.4$ \\
$11 \mathrm{mmol} / \mathrm{l} \mathrm{Glucose}+$ & $5.90 \pm 0.4$ & $7.44 \pm 0.5$ \\
$44 \mathrm{mmol} / \mathrm{l}$ Mannitol & & \\
\hline
\end{tabular}

Values are mean $\pm \mathrm{SD}(n=6)$

IGF-I, Insulin-like growth factor I

\begin{tabular}{|c|c|c|}
\hline & High glucose & Mannitol \\
\hline IGF-I binding & & \\
\hline $\begin{array}{l}\text { Thymidine incorporation } \\
\text { Basal }\end{array}$ & & $\overline{7}$ \\
\hline IGF-I stimulation & & \\
\hline $\begin{array}{l}\text { AIB uptake } \\
\text { Basal }\end{array}$ & t1 & $\rightarrow$ \\
\hline IGF-I stimulation & 141 & - \\
\hline 2-DOG uptake & $\rightarrow$ & - \\
\hline
\end{tabular}

Fig.5. Summary of the effects of high glucose and mannitol on the actions of insulin-like growth factor I(IGF-I) in cultured glomerular mesangial cells. AIB, $\alpha$-Aminoisobutylic acid; 2-DOG, 2-deoxyglucose

midine incorporation, both basal and IGF-I-stimulated uptake of AIB were significantly enhanced in the cells cultured under high glucose conditions in a dose-dependent manner (Fig.3). As shown in Figure 4 a, this enhancement of AIB uptake was not observed in the cells cultured in the presence of mannitol. Similar to thymidine incorporation, the dose-response curve of IGF-I (percent of maximal stimulated response) to stimulate AIB uptake was not different among control, high glucose, and mannitol groups (Fig.4b).

\section{2-Deoxyglucose uptake}

2-Deoxyglucose (2-DOG) uptake was examined in the cells cultured under control or high glucose conditions, or in the presence of mannitol. As shown in Table 1, no difference was observed among the three groups in either basal or IGF-I-stimulated uptake of 2-DOG.

The effect of glucose or mannitol on various IGF-I actions in cultured mesangial cells are summarized in Figure 5 .

\section{Discussion}

The present study indicates that the various actions of IGF-I in cultured glomerular mesangial cells are modulated differently by ambient glucose. Since glucose added to the culture media may cause extracellular hyperosmolality as well as intracellular metabolic abnormalities, mannitol was used to mimic the hyperosmolar effect of glucose. The binding of IGF-I to the mesangial cells increased slightly but significantly both under high glucose conditions and in the presence of mannitol. IGF-I-stimulated thymidine incorporation decreased in both conditions, though the decrease was more prominent under high glucose conditions. In contrast, both basal and IGF-Istimulated AIB uptake were enhanced only under high glucose conditions, and 2-DOG uptake was altered by neither high glucose nor mannitol. Therefore, high glucose seems to induce the up-regulation of the IGF-I receptor, the inhibition of the proliferative activity, and the enhancement of the amino acid uptake, while hyperosmolality may induce the up-regulation of the IGF-I receptor and the inhibition of the proliferative activity.

IGF-I receptors have been reported to be increased in kidneys from streptozotocin-induced diabetic rats and in mesangial cells isolated from diabetic mice $(\mathrm{db} / \mathrm{db})$ [15]. However, IGF-I receptor proteins have been reported to be unchanged when the mesangial cells from diabetic mice were cultured in high concentrations of glucose $(28 \mathrm{mmol} / \mathrm{l})$, though IGF-I mRNA levels increased [15]. Since, in the present study, the significant increase in ${ }^{125} \mathrm{I}$ IGF-I binding was observed only when the cells were cultured in an extremely high concentration of glucose $(55 \mathrm{mmol} / \mathrm{l})$ and a similar increase was observed when the cells were cultured in the presence of $\mathrm{NaCl}$ or mannitol, ambient hyperosmolality could be responsible for the increase in IGF-I binding in the mesangial cells. Although the effects of IGF binding proteins on IGF-I binding in cultured cells need to be considered, the reports are inconsistent $[16,17]$. However, because renal IGF binding proteins have recently been reported to be increased in diabetic rats [18], it might be necessary to examine the effect of glucose or mannitol on the expression of IGF binding proteins as well as to examine the biological roles of IGF binding proteins in the mesangial cells.

Despite the increase in IGF-I binding, IGF-I-stimulated $\left[{ }^{3} \mathrm{H}\right]$-thymidine uptake was significantly reduced in the mesangial cells cultured in high concentrations of glucose. The reduction was observed when the cells were cultured in a moderately high glucose concentration $(27.5 \mathrm{mmol} / 1)$. The dose-response curve of IGF-I indicates that this reduction might be due to post-receptor changes in IGF-I action. Glucose-induced impairment of the proliferation of the cells does not seem to be specific to IGF-I, because the impairment of the proliferation has been reported in human mesangial cells stimulated by $10 \%$ serum containing insulin, selenium and transferrin [19] or in human fetal mesangial cells stimulated by $2 \%$ fetal calf serum [20]. Therefore, glucose might inhibit the proliferation of the mesangial cells in the step(s) common to the various growth factors. The mechanism of the effect of glucose has been examined in other types of the cells. In cultured human umbilical endothelial cells, glucose has been suggested to cause the replicative delay between the phase of DNA synthesis and mitosis [21] possibly due to an increased number of single strand breaks of DNA [22]. In renal proximal tubular cells, the inhibitory effect of glu- 
cose on the cell proliferation has been reported to be abolished by the addition of the antibodies against transforming growth factor- $\beta$ and mRNA levels of this growth factor have been found to be increased in the cells cultured in high glucose [23]. Since these two mechanisms are completely different, it might be necessary to elucidate the mechanism of the inhibitory effect of glucose on the cell proliferation in the individual types of the cells. The study to examine the various steps of IGF-I action in the mesangial cells cultured under high glucose conditions is now in progress in our laboratory.

In contrast to the reduction of the proliferative response, the uptake of amino acid by the mesangial cells cultured in high concentrations of glucose was significantly enhanced both in the basal state and after the stimulation by IGF-I in a dose-dependent manner. The hypertonicity of the culture media is not likely to have been responsible as mannitol did not exert any effect on the AIB uptake. The dose-response curve of IGF-I again indicates that the enhancement could be due to the post-receptor changes in IGF-I action. Although the exact mechanism of the glucose-induced increase in amino acid uptake in the mesangial cells is unclear, this increase might induce the synthesis of protein(s) important to the mesangial cells. Since AIB has been reported to be incorporated into the cells via an amino acid uptake system similar to that for L-proline [24], the uptake of L-proline might also be enhanced under high glucose conditions. Because Lproline is an essential amino acid in the synthesis of collagens and a link between proline uptake and collagen synthesis has been reported [25], the increased proline uptake may result in an increase in type IV collagen production. This has been reported by us [4] and others [5] in mesangial cells cultured in high glucose.

The effect of glucose as an osmolyte has usually been evaluated by examining whether a poorly metabolizable osmolyte, such as mannitol, sorbitol or raffinose, is able to mimic the effect of glucose. In the present study, mannitol was able to mimic the effect of glucose on IGF-I binding and, partially, on IGF-I-stimulated $\left[{ }^{3} \mathrm{H}\right]$-thymidine incorporation. However, the reports concerning the effect of osmolytes are inconsistent. For example, Nahman et al. [19] have found that mannitol has no effect on cellular proliferation but significantly increases fibronectin production in cultured human mesangial cells. By contrast we have found that the production of type IV collagen in cultured mesangial cells is enhanced by glucose but not by mannitol [4]. Moreover, the production of heparan sulphate proteoglycan has been reported to be decreased by glucose but not by sorbitol in cultured porcine mesangial cells [26]. As Nahman et al. [19] stated, the mesangial cells were derived from a single human donor, which might limit extrapolation of the data to the general population. The results obtained in cultured human umbilical vein endothelial cells are more complex. Stout [27] has reported that the endothelial cell proliferation is inhibited by sorbitol similarly to glucose but not by mannitol. In endothelial cells, Lorenzi et al. [21] have found that mannitol is able to mimic the inhibitory effect of glucose on cell proliferation. Further study will be necessary to explore the effect of glucose as an osmolyte.
The present study indicates that the effects of IGF-I on the mesangial cells are altered under high glucose conditions probably at the level of post-IGF-I receptor binding. Glucose-induced changes affect IGF-I actions differently, resulting in a decrease in cell proliferation and an increase in amino acid uptake without significant change in glucose uptake. Although these results were mainly obtained in the mesangial cells cultured in relatively higher concentrations $(55 \mathrm{mmol} / \mathrm{l})$ of glucose, it might be necessary to expose the cells to higher concentrations of glucose to detect it's effect in these acute experiments. Since the effect of glucose was observed in a dose-dependent manner, lower concentrations of glucose might be enough to induce these changes if the cells have long-term exposure to glucose as occurs in diabetes.

Although these results were obtained in mesangial cells cultured in vitro, the present study might provide an explanation of the pathogenesis of diabetic nephropathy. First, even at normal levels of IGF-I, these results, in conjunction with the increased production of type IV collagen $[4,5]$, may be related to the development of the mesangial expansion with the relatively small increase in mesangial cell volume seen in diabetic nephropathy. Secondly, if locally-produced IGF-I which is increased in diabetic kidneys [9], is able to reach the mesangial cells, these alterations might be augmented. Therefore, our study indicates the importance of IGF-I and the glucoseinduced changes on IGF-I action in the development of diabetic nephropathy.

Acknowledgements. This study was supported in part by a grant from the Ministry of Education, Science and Culture, Japan ( \# 03671143). We are grateful to Y.Horie-Togawa and $\mathrm{H}$. Osato for their excellent technical assistance.

\section{References}

1. Mauer SM, Steffes MW, Brown DM (1981) The kidney in diabetes. Am J Med 70: 603-612

2. Steffes MW, Bilous RW, Sutherland DFR, Mauer SM (1992) Cell and matrix components of the glomerular mesangium in type I diabetes. Diabetes 41: 679-684

3. Abrass CK, Peterson CV, Raugi GJ (1988) Phenotypic expression of collagen types in mesangial matrix of diabetic and nondiabetic rats. Diabetes 37: 1695-1702

4. Haneda M, Kikkawa R, Horide N et al. (1991) Glucose enhances type IV collagen production in cultured rat glomerular mesangial cells. Diabetologia 34: 198-200

5. Ayo SH, Radnik RA, Garoni JA, Glass WF II, Kreisberg JI (1990) High glucose causes an increase in extracellular matrix proteins in cultured mesangial cells. Am J Pathol 136: 1339-1348

6. Conti FG, Striker LJ, Lesniak MA, MacKay K, Roth J, Striker GE (1988) Studies on binding and mitogenic effect of insulin and insulin-like growth factor I in glomerular mesangial cells. Endocrinology 122: 2788-2795

7. Arnqvist HJ, Ballermann BJ, King GL (1988) Receptors and effects of insulin and IGF-I in rat glomerular mesangial cells. Am J Physiol 254: C411-C416

8. Haneda M, Kikkawa R, Togawa M, Koya D, Kajiwara N, Shigeta Y (1991) Metabolic actions of insulin-like growth factor I in cultured glomerular mesangial cells. Metabolism 40: 1311-1316

9. Flyvbjerg A, Thorlacius-Ussing O, Naeraa R, Ingerslev J, Ørskov H (1988) Kidney tissue somatomedin $\mathrm{C}$ and initial renal 
growth in diabetic and uninephrectomised rats. Diabetologia 31: 310-314

10. Kikkawa R, Umemura K, Haneda M, Arimura T, Ebata K, Shigeta Y (1987) Evidence for existence of polyol pathway in cultured rat mesangial cells. Diabetes 36: 240-243

11. Freychet P, Roth J, Neville DM Jr (1971) Monoiodoinsulin: demonstration of its biological activity and binding to fat cells and liver membrane. Biochem Biophys Res Commun 43: 400-408

12. Flier JS, Usher P, Moses AC (1986) Monoclonal antibody to the type I insulin-like growth factor (IGF-I) receptor blocks IGF-I receptor-mediated DNA synthesis: clarification of the mitogenic mechanisms of IGF-I and insulin in human skin fibroblasts. Proc Natl Acad Sci USA 83: 664-668

13. Knight AB, Rechler MM, Romanus JA, Van Obberghen-Schiling EE, Nissley SP (1981) Stimulation of glucose incorporation and amino acid transport by insulin and insulin-like growth factor in fibroblasts with defective insulin receptors cultured from a patient with leprechaunism. Proc Natl Acad Sci USA 78: 2554 2558

14. McClain DA, Maegawa H, Lee J, Dull TJ, Ulrich A, Olefsky JM (1987) A mutant insulin receptor with defective tyrosine kinase displays no biologic activity and does not undergo endocytosis. J Biol Chem 262: 14663-14671

15. Oemar BS, Foellmer HG, Hodgdon-Anandant L, Rosenzweig SA (1991) Regulation of insulin-like growth factor I receptors in diabetic mesangial cells. J Biol Chem 266: 2369-2373

16. De Vroede MA, Tseng LY-H, Katsoyannis PG, Nissley SP, Rechler MM (1986) Modulation of insulin-like growth factor I binding to human fibroblast monolayer cultures by insulin-like growth factor carrier proteins released to the incubation media. J Clin Invest 77: 602-613

17. Ritvos O, Ranta T, Jalkanen J et al. (1988) Insulin-like growth factor (IGF) binding protein from human decidua inhibits the binding and biological action of IGF-I in cultured choriocarcinoma cells. Endocrinology 122:2150-2157

18. Flyvbjerg A, Kessler U, Dorka B, Funk B, Ørskov H, Kiess W (1992) Transient increase in renal insulin-like growth factor binding proteins during initial kidney hypertrophy in experimental diabetes in rats. Diabetologia 35: 589-593

19. Nahman NS Jr, Leonhart KL, Cosio FG, Hebert CL (1992) Effects of high glucose on cellular proliferation and fibronectin pro- duction by cultured human mesangial cells. Kidney Int 41: 396 402

20. Moran A, Brown DM, Kim Y, Klein DJ (1991) Effects of IGF-I and glucose on protein and proteoglycan synthesis by human fetal mesangial cells in culture. Diabetes 40: 1346-1354

21. Lorenzi M, Cagliero E, Toledo S (1985) Glucose toxicity for human endothelial cells in culture. Delayed replication, disturbed cell cycle, and accelerated death. Diabetes 34:621-627

22. Lorenzi M, Montisano DF, Toledo S, Barrieux A (1986) High glucose induces DNA damage in cultured human endothelial cells. J Clin Invest 77: 322-325

23. Rocco MV, Chen Y, Goldfarb S, Ziyadeh FN (1992) Elevated glucose stimulates TGF- $\beta$ gene expression and bioactivity in proximal tubule. Kidney Int 41: 107-114

24. Gazzola GC, Dall'Asta V, Guidotti GG (1980) The transport of neutral amino acids in cultured human fibroblasts. J Biol Chem 255:929-936

25. Ardaillou N, Nivez M-P, Bellon G, Combe C, Ardaillou R (1990) Effect of prostaglandin $\mathrm{E}_{2}$ on proline uptake and protein synthesis by cultured human mesangial cells. Kidney Int 38: 11511158

26. Olgemoller B, Schwaabe S, Gerbitz KD, Schleicher ED (1992) Elevated glucose decreases the content of a basement membrane associated heparan sulphate proteoglycan in proliferating cultured porcine mesangial cells. Diabetologia 35: 183-186

27. Stout RW (1982) Glucose inhibits replication of cultured human endothelial cells. Diabetologia 23: 436439

Received: 7 September 1992

and in revised form: 16 November 1992

Dr. R. Kikkawa

The Third Department of Medicine Shiga University of Medical Science Seta, Otsu

Shiga 520-21

Japan 